\title{
Mercury concentrations in eggshells of the Southern Ground- Hornbill (Bucorvus leadbeateri) and Wattled Crane (Bugeranus carunculatus) in South Africa
}

\author{
Adegbenro P. Daso ${ }^{1^{*}}$, Jonathan O. Okonkwo², Ray Jansen ${ }^{2}$, José DDO. \\ Brandao $^{2}$, Antoinette Kotzé ${ }^{3}$
}

${ }^{1}$ Department of Chemistry, Faculty of Natural and Agricultural Sciences, University of Pretoria, Private Bag X20, Hatfield 0028, Pretoria, South Africa.

${ }^{2}$ Department of Environmental, Water and Earth Sciences, Tshwane University of Technology, 175 Nelson Mandela Drive, Private Bag X680, Arcadia, Pretoria, South Africa.

${ }^{3}$ National Zoological Gardens of South Africa, P.O. Box 754, Pretoria 0001, South Africa

*Corresponding author: Tel: +27789027213, +27746546510; Fax: +27124204687; adegbenrop@gmail.com; adegbenrop@yahoo.com

\section{Highlights}

- Total mercury concentrations in hatched eggshells of threatened birds were determined

- Observed $\mathrm{Hg}$ levels exceeded those estimated to cause adverse reproductive effects in birds

- Exposure of investigated birds to environmental $\mathrm{Hg}$ might be playing some contributory roles to their declining population trends.

\section{Abstract}

In this study, wild hatched eggshells were collected from the nests of the threatened Wattled Crane and South Ground-Hornbill in an attempt to determine total $\mathrm{Hg}$ concentrations. A total of fourteen eggshell samples from both bird species were collected from different study areas in the Mpumlanga and KwaZulu-Natal Provinces, South Africa. The eggshells were acid digested under reflux and their total $\mathrm{Hg}$ contents were determined using cold-vapour atomic absorption spectrophotometry (CV-AAS). The observed total $\mathrm{Hg}$ levels for the South Ground-Hornbill samples ranged from 1.31 to $8.88 \mu \mathrm{g} / \mathrm{g}$ dry weight (dw), except for one 
outlier which had an elevated $75.0 \mu \mathrm{g} / \mathrm{g} \mathrm{dw}$. The levels obtained for the Wattled Crane samples were relatively higher and these ranged from 14.84 to $36.37 \mu \mathrm{g} / \mathrm{g} \mathrm{dw}$. Generally, all the measured total $\mathrm{Hg}$ concentrations for the Wattled Crane samples exceeded the estimated total $\mathrm{Hg}$ levels derived for eggshell which were known to cause adverse reproductive effects in avian species from previous studies. Based on these findings, it is, therefore, possible that the exposure of these birds to elevated $\mathrm{Hg}$ may have contributed to their present population decline.

Keywords: Total mercury, Wattled Crane, Southern Ground-Hornbill, reproduction, eggshells.

\section{Introduction}

Mercury $(\mathrm{Hg})$, in its different forms, has become an important environmental contaminant of global concern where several natural and anthropogenic sources continue to contribute to its growing release into the environment. Notably, emissions from coal-fired power stations and artisanal gold mining practices were identified as the major anthropogenic $\mathrm{Hg}$ sources (Williams et al., 2010; Walters et al., 2011). In South Africa, where there is unprecedented dependence on coal for energy generation, coal combustion has remained a leading source of $\mathrm{Hg}$ pollution. Presently, South Africa is ranked amongst the topmost emitters of $\mathrm{Hg}$ contributing more than $10 \%$ to the global Hg emissions (Pacyna et al., 2010).

Both the South Ground-Hornbill (SGH) (Bucorvus leadbeateri) and Wattled Crane (WC) (Bugeranus carunculatus) populations have been declared to be under significant threat (Burke and Rodwell, 2000). Presently, these two large avian species are amongst the South African wild birds listed on the International Union for the Conservation of Nature (IUCN) red list of globally threatened birds as vulnerable and critically endangered, respectively (Burke and Rodwell, 2000). These birds are widely distributed in the southern Africa region, 
especially in countries such as Angola, Botswana, Democratic Republic of Congo, Malawi, Mozambique, Namibia, Zambia and South Africa.

Regardless of their geographical location, habitat destruction which is mostly linked to increased agricultural, industrial and other human-related activities has been implicated as possible factor contributing to their rapid population decline. Furthermore, increased livestock grazing and anthropogenic disturbances in close proximity to their breeding sites are also responsible for their declining breeding success. In addition, accidental and purposeful poisoning of both species has been reported where birds have ingested poisoned baits set out for problematic animals or baits were laid out specifically to kill birds for the traditional medicine market (Burke and Rodwell, 2000; Engelbrecht et al., 2007). While the various physical threats and their impacts on the continued survival of these threatened birds have been documented, the potential deleterious effects as a result of their exposure to elevated levels of harmful environmental pollutants, particularly within their habitat have not been properly considered. The present study, therefore, aims to evaluate the total mercury concentrations in eggshells of these threatened birds whether they exceed the effect thresholds previously established for other species in the literature.

\section{Materials and Method}

\section{Sampling sites, sample collection and preparation and instrumental analysis}

In this study, the total $\mathrm{Hg}$ concentrations of fourteen (14) hatched eggshell samples were determined. Of these, 8 eggshell samples were obtained from the ground-hornbill, which were collected from different nest sites within the Kruger National Park during 2012 and 2013 breeding seasons. The remaining 6 were crane eggshells, which were also collected from different nest sites within the KwaZulu-Natal midlands in 2011. The limited sample size employed in this study was due to the present conservation status of both bird species as well as their unique reproductive behaviours where fully matured female birds only lay a maximum of two eggs. For clarity, individual eggshells from both species were collected from 
different nests. The detailed description of the crane samples is provided in the Supplementary Table 1.

With respect to their reproductive and breeding behaviours, these birds are known to lay a maximum of two eggs but only rear one chick. Usually, the first chick hatched by the groundhornbill, for instance, outcompetes its younger and weaker sibling, thus only one chick usually survives (Kemp and Kemp, 1991). Incidentally, the only surviving chick could also be lost via other forms of man-made and natural threats, including forest fires, poaching, or even as a prey to some carnivorous animals. Due to their imminent path to irreversible population decline in South Africa, several conservation efforts, including the Wattled Crane Recovery Programme (WCRP) and Mabula Ground-Hornbill Conservation Project were initiated to mitigate these identified physical threats (Barnes, 2000; Theron et al., 2008).

The crane eggshells were collected from each nest once the eggs had hatched and the chicks had moved off with the parents. Similarly, hatched eggshells of the ground-hornbill were removed from each nest by staff of the Mabula Ground Hornbill Project at the time the second chick was collected for hand-rearing purposes as this second chick is not fed by the parents and dies. Incidentally, these sampling locations are situated in close proximity to important hotspots for $\mathrm{Hg}$ in their respective localities.

During the sample preparation, the dried membrane in the crane samples were carefully separated from the eggshells. The cleaned and dried eggshell were then ground and stored in well labelled self-sealing polyethelene bags. In contrast, due to the fragile nature of the ground-hornbill samples which prevents the separation of eggshell from the dried membrane, each sample was treated as one ground mass.

The sampling locations as well as the associated activities related to $\mathrm{Hg}$ releases into the environment are shown in Figure 1. It is equally important to point out that a large open cast copper mine with smelter and a phosphate mine is located just south of the town of Phalaborwa adjacent to the Kruger National Park and the Umgeni River catchment traverses the crane sampling location just north of the town of Pietermaritzburg. In 1990's, Hgcontaining effluents were reportedly discharged into the Umgeni river catchment. Thus, this 


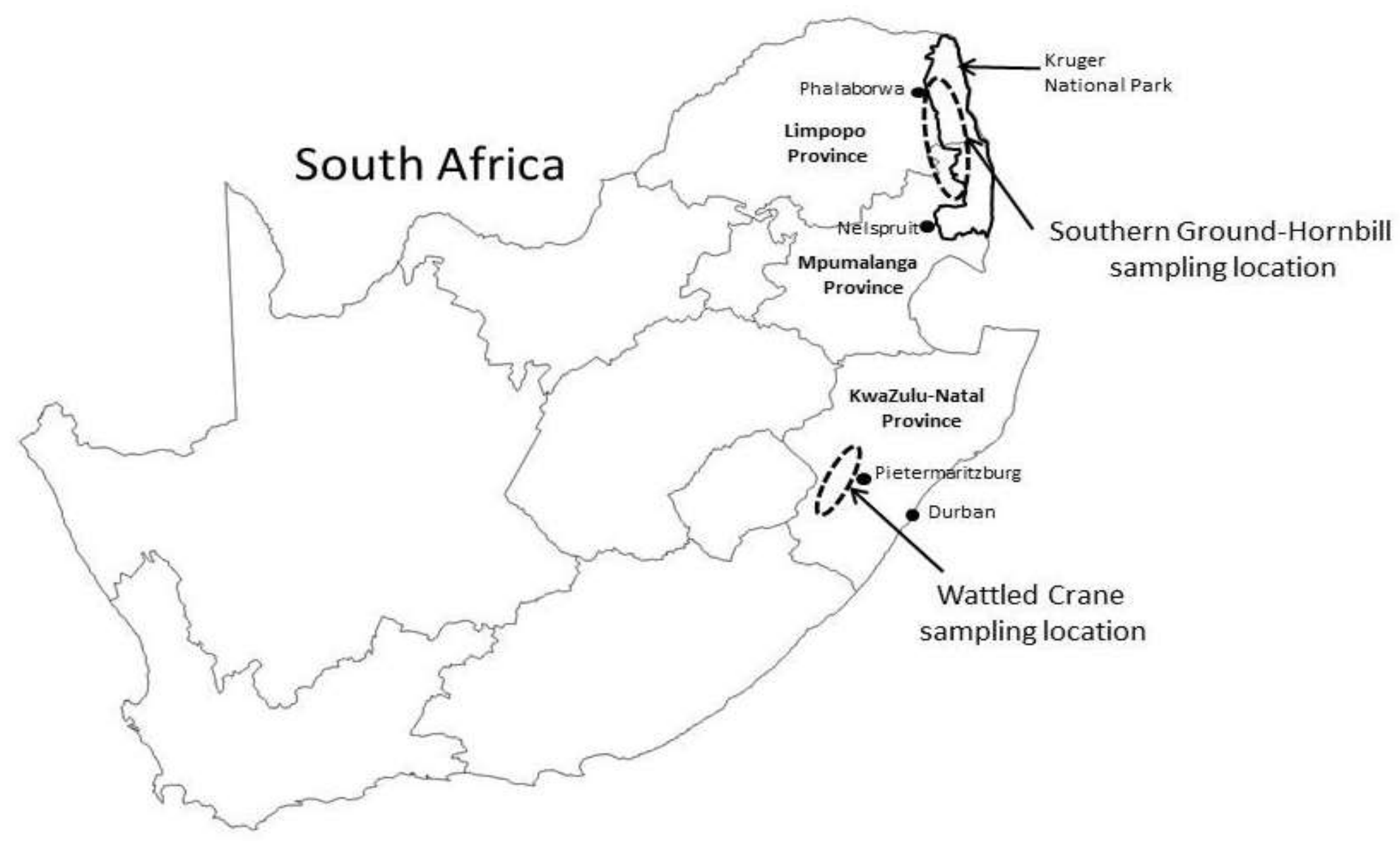

Figure 1: Map of the study areas showing the sampling locations within the three South African Provinces 
area is now considered as "historically contaminated with $\mathrm{Hg}$ " within the Kwa-Zulu Natal Province. Several years after the discontinuation of the discharges, total $\mathrm{Hg}$ levels exceeding the global average of $5 \mathrm{ng} \mathrm{L}^{-1}$ for surface waters were reported within the Umgeni river catchment (Williams et al., 2011).

The procedures for the determination of total $\mathrm{Hg}$ in eggshell samples in this study were derived from the established cold vapour atomic absorption spectrometric (CV-AAS) technique (USEPA Method 245.1, revision 3), previously developed for the determination of $\mathrm{Hg}$ in water samples, with some modifications. Briefly, approximately $1 \mathrm{~g}$ of dried eggshell sample was weighed and transferred into clean round bottom flask. The eggshell sample was suspended in $100 \mathrm{~mL}$ of ultrapure water (Siemens LaboStar ${ }^{\mathrm{TM}} \mathrm{D} 14$ system, Germany) to which $5 \mathrm{~mL}$ of $0.5 \mathrm{~N} \mathrm{H}_{2} \mathrm{SO}_{4}$ and $2.5 \mathrm{~mL}$ of $\mathrm{HNO}_{3}(1+1)$ (Sigma-Aldrich, South Africa) were added. Thereafter, $15 \mathrm{~mL}$ of freshly prepared $\mathrm{KMnO}_{4}(50 \mathrm{~g}$ in $1000 \mathrm{~mL})$ (Sigma-Aldrich, South Africa) was added followed by the addition of $8 \mathrm{~mL}$ of $\mathrm{K}_{2} \mathrm{~S}_{2} \mathrm{O}_{8}(25 \mathrm{~g}$ in $500 \mathrm{~mL}$ ) (Sigma-Aldrich, South Africa). Finally, 5 acid pre-washed boiling chips were added to prevent bumping during heating. The samples were then heated under reflux for two hours on a heating block. After the digestion, the samples were allowed to cool to room temperature. The samples were then filtered and $6 \mathrm{~mL}$ of sodium chloride-hydroxylamine hydrochloride solution was added to reduce the excess permanganate. The samples were then made up to the $250 \mathrm{~mL}$ mark and kept in the refrigerator until analysis.

The total $\mathrm{Hg}$ concentrations of the eggshell samples was determined with a Shimadzu AA6300 Atomic Absorption Spectrometer (Tokyo, Japan) equipped with mercury vapour unit. The optimum conditions employed for the $\mathrm{Hg}$ analysis are presented in Supplementary Table 2. The analysis was performed in a close-circuit system and the $\mathrm{Hg}$ vapours leaving the absorption cell were trapped in $\mathrm{KMnO}_{4}$ solution contained in the waste bottle. 


\section{Quality Control and Quality Assurance}

To avoid possible contamination, glassware was soaked in dilute nitric acid for at least $24 \mathrm{~h}$. Similarly, the pestles and mortars employed for grinding were thoroughly washed and dried overnight in the oven. Laboratory reagent blanks (LRBs) as well as laboratory fortified blanks (LFBs) were prepared to assess potential contamination within the laboratory and to ascertain the laboratory performance, respectively. The mean $\mathrm{Hg}$ levels in the LRBs were deducted from all the results obtained.

Furthermore, matrix spike experiments were performed where a laboratory matrix (domestic chicken eggshell) was employed. In this case, each of the three replicates was spiked with $0.5 \mu \mathrm{g}$ of $\mathrm{Hg}$ in order to determine the accuracy of the method. Recoveries ranging from 66.4 to $97 \%$ were obtained. Although, these were consistent with the USEPA recommendations for total $\mathrm{Hg}$ determination, hence, the results obtained in this study were not recovery corrected. However, due to the compositional differences between the laboratory matrix and the real eggshell samples, the possibility of inconsistency in the overall accuracy of the method cannot be ruled out. As a result, the reported $\mathrm{Hg}$ levels in the analysed samples may have been underestimated.

\section{Results and Discussion}

\section{Inter-species variations in total $\mathrm{Hg}$ concentrations of eggshell samples}

The results obtained for the total $\mathrm{Hg}$ determination in hatched eggshells of the investigated birds are presented in Table 1. Due to the limited sample quantities, only single measurements were performed for all the ground-hornbill samples. However, duplicate analyses were performed for most of the crane eggshell samples except for samples I and J, in which single measurements were performed. Generally, the total $\mathrm{Hg}$ concentrations were relatively higher in the crane samples than those found in the ground-hornbill samples. Nevertheless, the highest total $\mathrm{Hg}$ concentration $\left(75 \mu \mathrm{g} \mathrm{g}^{-1}, \mathrm{dw}\right)$ was obtained in a groundhornbill sample which was several of orders of magnitude higher than those found in other 
Table 1: Concentrations of the total $\mathrm{Hg}(\mu \mathrm{g} / \mathrm{g}, \mathrm{dw}$ ) in eggshell samples of Southern Ground-Hornbill and Wattled Crane.

\begin{tabular}{|c|c|c|c|c|c|c|c|c|}
\hline Species (SGH) & & & & & & & & \\
\hline Sample code & A & B & $\mathrm{C}$ & $\mathrm{D}$ & $\mathrm{E}$ & $\mathrm{F}$ & G & $\mathrm{H}$ \\
\hline Concentrations & 5.10 & 6.37 & 2.01 & 75.0 & 8.88 & 1.31 & 2.73 & 6.04 \\
\hline \multicolumn{9}{|l|}{ Species (WC) } \\
\hline Sample code & I & $\mathrm{J}$ & K & $\mathrm{L}$ & M & $\mathrm{N}$ & & \\
\hline Mean & 16.29 & 14.84 & 21.26 & 28.42 & 25.40 & 26.59 & & \\
\hline Range & - & - & $17.42-25.10$ & $20.48-36.37$ & $24.88-25.91$ & $22.23-30.95$ & & \\
\hline
\end{tabular}

SGH - South Ground-Hornbill; WC - Wattled Crane; dw - dry weight. 
eggshells from the same bird species. With the exclusion of this outlier, the overall mean total $\mathrm{Hg}$ concentration for crane $\left(23.45 \mu \mathrm{g} \mathrm{g}^{-1}, \mathrm{dw}\right)$ was about 5-fold higher than that obtained for the ground-hornbill samples.

Generally, the total $\mathrm{Hg}$ variations between these two species can be due to a number of factors or combinations of exposure variations, trophic level considerations, locational or geographical differences in $\mathrm{Hg}$ concentrations in soil, water and air, and species-specific absorption rates (Burger and Gochfeld, 1997). It is equally necessary to take into account that the total $\mathrm{Hg}$ concentrations in avian eggs are mostly a reflection of the recent dietary uptake rather than via contributions from accumulated tissue stores (Wolfe et al., 1998). Therefore, the measured total $\mathrm{Hg}$ concentrations in the eggshells of both species could serve as a reliable indicator of exposure to $\mathrm{Hg}$ in the vicinity of their breeding site prior to their laying season.

The ground-hornbill is a predatory species in terrestrial grasslands, savannah and woodlands where its diet ranges from a variety of invertebrates, reptiles, amphibians, tortoises to small mammals (Kemp, 2005); whereas the crane forages predominantly in wetlands for tubers and grass seeds but they have also been known to forage on small aquatic snails, fish and frogs (Allan, 2005) and sometimes, their young chicks also feed on insects (Hancock, 2003). These factors could further explain some of the observed differences in the total $\mathrm{Hg}$ concentrations measured in their eggshells.

Recent findings suggest that mining activities could significantly contribute to excessive accumulation of selected heavy metals in certain plant species (Kendall, 2014). Given the dietary preferences of these birds, the uptake of $\mathrm{Hg}$ via the consumption of aquatic flora and fauna might represent important contributors to the relatively high total $\mathrm{Hg}$ levels observed amongst the crane species. Other possible sources of $\mathrm{Hg}$ within the study areas include the prolong use of mercury-based pesticides and through the unpopular artisanal gold mining practices. Furthermore, the sampling sites for crane are situated within the same water management area (WMA) known to have been historically impacted with $\mathrm{Hg}$ pollution. 
A major disadvantage with respect to the use of birds as bio-indicators of environmental pollutants is their mobility. Consequently, the observed pollutant levels in any part of a bird might not necessarily reflect its immediate environmental conditions. However, the use of avian eggshells as indicators of environmental contaminants is rather advantageous as it often reflects the exposure of female birds to harmful contaminants within their nesting sites prior to egg laying. Generally, there was less disparity in the mean total $\mathrm{Hg}$ concentrations in crane eggshells, which ranged between 14.84 and $28.42 \mu \mathrm{g} \mathrm{g}^{-1}$, dw when compared with those of the SGH $\left(1.31-75.0 \mu \mathrm{g} \mathrm{g}{ }^{-1}, \mathrm{dw}\right)$. With the exclusion of considerably high total $\mathrm{Hg}$ from one particular ground-hornbill sample, there was no apparently large difference in the total $\mathrm{Hg}$ concentrations amongst the ground-hornbill samples. This elevated sample may be in close proximity to a potential $\mathrm{Hg}$ source within the study areas. It is, however, difficult to associate the outlier with any possible sources of $\mathrm{Hg}$ within the study area due to their mobility. Although, it was observed that the ground-hornbills within the Kruger National Park, for instance, could have clearly defined home ranges that may range between 10 and 20 ha (Theron et al., 2013). On the other hand, the cranes are largely non-migratory and will only travel outside their foraging sites if there is severe seasonal water shortage (Ndirima, 2007).

\section{Assessing ecological risks associated with $\mathrm{Hg}$ levels in investigated birds}

Owing to the present status of these threatened birds, the use of fresh egg which is conventional to assessing pollutant's levels in avian eggs is highly discouraged. Since it is crucial to understand the underlying factors contributing to their declining population trends, the use of hatched eggshells is an attempt to evaluate the extent of their exposure to environmental $\mathrm{Hg}$.

For avian species, the most important toxicological endpoints associated with exposure to $\mathrm{Hg}$ are those related to reproduction. These could produce effects such as reduced hatchability, eggshell thinning, reduced clutch size, and increased numbers of eggs laid outside the nest, aberrant behaviours of juveniles, amongst others. Therefore, the 
relationship between the observed total $\mathrm{Hg}$ concentrations in avian eggs or eggshells and their associated adverse effects are useful indicators to evaluate their potential reproduction risks.

Laboratory studies show that mercury levels of $1.5 \mathrm{\mu g} \mathrm{g}^{-1}$ in avian species are associated with adverse effects, including impaired reproduction (Aliakbari et al., 2011). Unfortunately, it is difficult to make a good extrapolation employing this benchmark which is established for the whole egg samples since the total $\mathrm{Hg}$ concentrations were only obtained for the eggshell samples in the present study. It is, therefore, needful to rely on the available information in the literature to predict $\mathrm{Hg}$ distribution in the different components of the egg of avian species. One of such studies is that recently reported for Gentoo penguins where up to $92.0 \%$ of the total $\mathrm{Hg}$ in their eggs were allocated to the albumen, $6.7 \%$ in the yolk, $0.4 \%$ in the membrane and $0.9 \%$ in the eggshell (Brasso et al., 2012).

To derive an appropriate adverse effect estimate using the $0.9 \%$ composition of total $\mathrm{Hg}$ in eggshell, a concentration of $0.0135 \mu^{-1} \mathrm{~g}^{-1}$ wet-weight is obtained as a suitable cut-off for assessing the potential reproductive risks via exposure of these birds to environmental $\mathrm{Hg}$. For better interpretation of the obtained results, it will be necessary to convert the predicted adverse effect estimate on a dry-weight basis. Assuming the average moisture content of these eggs is $70 \%$, then the estimated adverse effect level of total $\mathrm{Hg}$ on dry-weight basis will be equivalent to $0.4054 \mathrm{ppm}$. A comparison of the total $\mathrm{Hg}$ concentrations obtained for the eggshell samples for both bird species with this benchmark indicated that the total $\mathrm{Hg}$ levels in all the investigated samples exceeded the estimated adverse effect benchmark. Based on these calculations and other extrapolations made from previous studies which are presented in Table 2, we conclude that the exposure of the investigated birds to elevated environmental $\mathrm{Hg}$ might be contributing to the rapidly declining population of these birds.

There are a number of other important factors that need to be considered while evaluating the ecological risks to avian populations. Some of these include: the age of the bird, lifespan, maximum body weight, feeding and excretion rates, fledging age, reproductive maturity, length of stay at breeding sites prior to egg laying, and type of habitat (protected area or 
Table 2: Estimated total mercury levels in avian eggshells (ppm) associated with adverse effects in birds derived from total mercury levels established for egg content

\begin{tabular}{|c|c|c|c|c|}
\hline Species & $\begin{array}{l}\text { Reported level (ppm) for } \\
\text { egg content }\end{array}$ & $\begin{array}{l}{ }^{*} \text { Estimated equivalent } \\
\text { level (ppm, dry } \\
\text { weight) for eggshell }\end{array}$ & Observed effects & References \\
\hline \multirow{4}{*}{$\begin{array}{l}\text { Pheasant (Phasianus } \\
\text { colchicus) }\end{array}$} & $0.05-1.5($ ww) & $0.0015-0.045$ & Reduced hatchability & Fimreite (1971) \\
\hline & & & Reduced chick survival & \\
\hline & & & Reduced egg weight & \\
\hline & & & Shell-less eggs & \\
\hline \multirow[t]{2}{*}{ Pheasant } & $0.9-3.1(w w)$ & $0.027-0.093$ & $\begin{array}{l}\text { Reduced hatch rate (by } \\
50-80 \% \text { ) }\end{array}$ & Spann et al. (1972) \\
\hline & & & Reduced chick survival & \\
\hline $\begin{array}{l}\text { Black duck (Anas } \\
\text { rubripes) }\end{array}$ & $5.53(\mathrm{ww})$ & 0.166 & Lower hatchability & $\begin{array}{l}\text { Finley and Stendell } \\
(1978)\end{array}$ \\
\hline \multirow[t]{11}{*}{$\begin{array}{l}\text { Mallard (Anas } \\
\text { platyrynnchos) }\end{array}$} & 0.53 (ww) & 0.016 & Increased mortality & $\begin{array}{l}\text { Hoffman and Moore } \\
\text { (1979) }\end{array}$ \\
\hline & & & $\begin{array}{l}\text { Decreased embryonic } \\
\text { growth }\end{array}$ & \\
\hline & & & 58\% abnormal chicks & \\
\hline & 0.7 (ww) & 0.021 & Embryo malformation & Heinz (1975) \\
\hline & & & $27 \%$ abnormal chicks & \\
\hline & $0.5-0.9(w w)$ & $0.015-0.027$ & Lower hatching rate & $\begin{array}{l}\text { Heinz (1974), Heinz } \\
\text { (1976b), Heinz (1976a) }\end{array}$ \\
\hline & & & $\begin{array}{l}\text { Decreased embryonic } \\
\text { growth }\end{array}$ & \\
\hline & & & 58\% abnormal chicks & \\
\hline & $5.46(\mathrm{dw})$ & 0.049 & Reduced survival rate & \\
\hline & 1.0 (ww) & 0.030 & $\begin{array}{l}\text { Chicks hyper-responsive } \\
\text { to frightening stimuli }\end{array}$ & Heinz (1976b) \\
\hline & $5.46(\mathrm{dw})$ & 0.049 & $\begin{array}{l}\text { Eggs of chicks from } \\
\text { eggs with these levels } \\
\text { had thinner shells }\end{array}$ & Heinz (1979) \\
\hline $\begin{array}{l}\text { Common tern (Sterna } \\
\text { hirundo) }\end{array}$ & 3.65 (ww) & 0.110 & Reproductive failures & (Fimreite (1974)) \\
\hline
\end{tabular}


wild), amongst others. For instance, the crane and ground-hornbill are relatively large birds with maximum body weight of up to $7.9 \mathrm{~kg}$ and $4.6 \mathrm{~kg}$, respectively. Their average lifespan is also estimated to be 20-30 years and 30-40 years, respectively. So far, there are no laboratory reports on the total $\mathrm{Hg}$ levels that can produce reproductive impairment in these birds. Therefore, it would be difficult to associate the total Hg levels in the eggshells of these birds with the adverse effects determined for other avian species without taking the aforementioned factors into consideration.

Laying of eggs by birds is often considered as a typical elimination mechanism by female birds to get rid of accumulated contaminants from their bodies. Sometimes, up to $5-20 \%$ of the contaminants present in their diet could be eliminated via egg laying (Falkowska et al., 2013). Given the relatively high total $\mathrm{Hg}$ levels observed in the present study, especially for the crane species, it remains unclear whether this elimination mechanism is an important adaptation strategy adopted by the birds to alleviate the detrimental effects of $\mathrm{Hg}$. We suggest that future studies should be focused on these possibilities. Ultimately, there is need to also look into the possible synergistic interactions of different pollutants and how these interactions contribute to the declining population of these threatened birds.

\section{Conclusions}

In this study, the possible contributory roles of $\mathrm{Hg}$ to the declining population of both Wattled Crane and South Ground-Hornbill were evaluated. The observed total Hg levels in their eggshells were considerably higher than those reported for other avian species. An assessment of the potential ecological risks that could be posed by the observed levels was performed. This revealed that the investigated birds might be susceptible to adverse effects of $\mathrm{Hg}$, including lower hatchability, reduced clutch size, reproductive failures, and reduced embryonic growth, amongst others. Because of the species-specific differences amongst the avian populations, we suggest that other factors such as the age of the bird, lifespan, maximum body weight, feeding and excretion rates, fledging age, and length of stay at the 
breeding sites prior to egg laying, amongst others, be considered, if the potential ecological risks that could be posed by a pollutant is to be evaluated for avian species with no established dose-response data. Finally, this study demonstrates that hatched eggshells of avian population, especially those that are considered threatened may be used noninvasively to evaluate their extent of exposure to environmental $\mathrm{Hg}$.

\section{Acknowledgements}

The technical assistance offered by the field staff of the Mabula Ground Hornbill Project and the Wattled Crane Recovery Programme in the collection of eggs and eggshell is gratefully acknowledged. The authors would also like to acknowledge the management of Tshwane University of Technology, Pretoria for providing laboratory facilities and other logistics. Finally, the authors would like to acknowledge the University of Pretoria for the Postdoctoral funding offered to AP Daso from the Vice Chancellor's Postdoctoral programme.

\section{References}

Aliakbari, A., Savabieasfahani, M., Ghasempouri, S., 2011. Mercury in egg and eggshell of whiskered tern (Chlidonias hybrida) from Anzali wetlands of the Caspian Sea, Iran. Bull Environ Contam Toxicol 86, 175-179.

Barnes, K.N., 2000. The Eskom red data book of birds of South Africa, Lesotho and Swaziland. BirdLife South Africa.

Brasso, R.L., Abel, S., Polito, M.J., 2012. Pattern of mercury allocation into egg components is independent of dietary exposure in Gentoo penguins. Archives of environmental contamination and toxicology $62,494-501$.

Burger, J., Gochfeld, M., 1997. Risk, mercury levels, and birds: relating adverse laboratory effects to field biomonitoring. Environmental Research 75, 160-172.

Burke, A., Rodwell, L., 2000. The South African wattled crane supplementation program. Special Bird Issue 20, 8. 
Engelbrecht, D., Theron, N., Turner, A., Van Wyk, J., Pienaar, K., 2007. The status and conservation of Southern Ground Hornbills, bucorvus leadbeateri, in the Limpopo Province, South Africa. The Active Management of Hornbills and their habitats for conservation, 252-266.

Falkowska, L., Reindl, A.R., Szumiło, E., Kwaśniak, J., Staniszewska, M., Bełdowska, M., Lewandowska, A., Krause, I., 2013. Mercury and chlorinated pesticides on the highest level of the food web as exemplified by herring from the Southern Baltic and African penguins from the zoo. Water, Air, \& Soil Pollution 224, 1-15.

Hancock, P., 2003. Wattled Crane research and monitoring in the Okavango Delta-2002. Babbler 42, 5-9.

Kemp, A., Kemp, M., 1991. Timing of egglaying by Southern Ground-Hornbills Bucorvusleadbeateri in the central Kruger National-Park, South Africa. South African Ornithol Soc. PO Box 84394, Greenside 2034, South Africa, pp. 80-82.

Kendall, L., 2014. An assessment of the foliar heavy metal contamination in the Palabora mining region.

Ndirima, Z.K., 2007. Mapping and monitoring wetland vegetation used by wattled cranes using remote sensing: case of Kafue flats, Zambia. Unpublished MSc Thesis, ITC, Enschede.

Pacyna, E.G., Pacyna, J.M., Sundseth, K., Munthe, J., Kindbom, K., Wilson, S., Steenhuisen, F., Maxson, P., 2010. Global emission of mercury to the atmosphere from anthropogenic sources in 2005 and projections to 2020. Atmospheric Environment 44, 2487-2499.

Theron, N., Turner, A., Soorae, P., 2008. Ten years on: a re-introduction of Southern Ground Hornbill on Mabula Private Game Reserve in the Limpopo Province of South Africa. Global Re-introduction Perspectives. Re-introduction Case Studies from Around the World. IUCN/SSC Re-introduction Specialist Group. Abu Dhabi, UAE, 104-107. 
Walters, C.R., Somerset, V.S., Leaner, J.J., Nel, J.M., 2011. A review of mercury pollution in South Africa: Current status. Journal of Environmental Science and Health, Part A 46, $1129-1137$.

Williams, C., Leaner, J., Somerset, V., Nel, J., 2011. Mercury concentrations at a historically mercury-contaminated site in KwaZulu-Natal (South Africa). Environ Sci Pollut Res $18,1079-1089$.

Williams, C.R., Leaner, J.J., Nel, J.M., Somerset, V.S., 2010. Mercury concentrations in water resources potentially impacted by coal-fired power stations and artisanal gold mining in Mpumalanga, South Africa. Journal of Environmental Science and Health, Part A 45, 1363-1373.

Wolfe, M.F., Schwarzbach, S., Sulaiman, R.A., 1998. Effects of mercury on wildlife: a comprehensive review. Environmental Toxicology and Chemistry 17, 146-160. 
Supplementary Table 1: The physical characteristics of the Wattled Crane (Bugeranus carunculatus) egg samples.

\begin{tabular}{|c|c|c|c|c|c|c|c|c|}
\hline Species & Location & $\begin{array}{l}\text { Date of } \\
\text { collection }\end{array}$ & $\begin{array}{l}\text { Egg weight } \\
\text { (g) }\end{array}$ & $\begin{array}{l}\text { Egg length } \\
(\mathrm{cm})\end{array}$ & $\begin{array}{l}\text { Egg breadth } \\
(\mathrm{cm})\end{array}$ & $\begin{array}{l}\text { Date } \\
\text { pipped }\end{array}$ & Date hatched & $\begin{array}{l}\text { Date transferred } \\
\text { to Johannesburg } \\
\text { zoo }\end{array}$ \\
\hline$W C$ & $\begin{array}{l}\text { Rock farm, } \\
\text { Nottingham Rd. }\end{array}$ & $23-06-2011$ & 190 & 10.26 & 6.40 & $25-06-2011$ & $26-06-2011$ & $27-06-2011$ \\
\hline$W C$ & $\begin{array}{l}\text { Hopewell, } \\
\text { Nottingham Rd. }\end{array}$ & $26-06-2011$ & 196 & 9.68 & 6.68 & $28-06-2011$ & $29-06-2011$ & $30-06-2011$ \\
\hline$W C$ & Impendle Location & $27-06-2011$ & 197 & 10.62 & 6.53 & $27-06-2011$ & $28-06-2011$ & $30-06-2011$ \\
\hline$W C$ & Mbeche, Karkloof & $05-08-2011$ & 180 & 10.80 & 6.09 & $08-08-2011$ & $09-08-2011$ & $10-08-2011$ \\
\hline$W C$ & $\begin{array}{l}\text { Yorkshire Wild, } \\
\text { Kamberg }\end{array}$ & $10-07-2011$ & 211 & 10.51 & 6.77 & $13-07-2011$ & $15-07-2011$ & $15-07-2011$ \\
\hline$W C$ & $\begin{array}{l}\text { Crystal Waters, } \\
\text { Underberg }\end{array}$ & $12-08-2011$ & NR & 9.48 & 6.06 & $12-08-2011$ & $13-08-2011$ & $16-08-2011$ \\
\hline
\end{tabular}

WC - Wattled Crane; NR - not reported. 
Supplementary Table 2: Optimal instrumental conditions and calibration parameters employed for the total Hg determination

\begin{tabular}{|c|c|}
\hline Parameters & Optimum conditions \\
\hline \multicolumn{2}{|l|}{ Optics } \\
\hline - Lamp current low (mA) & 4.0 \\
\hline - Wavelength (nm) & 253.7 \\
\hline - Slit width (nm) & 0.7 \\
\hline \multicolumn{2}{|l|}{ Atomizer set-up } \\
\hline - Fuel gas flow rate (L/min) & 1.8 \\
\hline - Support gas flow rate (L/min) & 15.0 \\
\hline - Burner head (mm) & 20.0 \\
\hline - Burner angle (degree) & 0.0 \\
\hline \multicolumn{2}{|l|}{ Calibration } \\
\hline - Calibration range $(\mu \mathrm{g} / \mathrm{L})$ & $0.5-4.0$ \\
\hline - Correlation co-efficient (R) & 0.9999 \\
\hline - Calibration curve equation & $\mathrm{Abs} .=0.0049442 \mathrm{Conc} .+0.00080233$ \\
\hline
\end{tabular}

